\title{
The Muslim Calendar
}

Ibn Battuta reports the dates of his travels according to the Muslim calendar, which is based on the cycles of the moon. The Muslim year is divided into twelve lunar months of 29 or 30 days each. The year is approximately 354 days long, that is, ten or eleven days shorter than a solar year. Consequently, dates of the Muslim calendar have no fixed relationship either to dates of the Gregorian (Western) calendar or to seasons of the year. For example, Christmas is always celebrated in winter in Europe and the United States. By contrast, a Muslim religious holiday will, over time, occur in all four seasons of the year. The base-year of the Muslim calendar is 622 A.D., when the Prophet Muhammad and his followers made the hijra, or "migration," from Mecca to Medina. The abbreviation A.H., for anno Hejirae, denotes years of the Muslim calendar. In this book I have given key dates according to both calendars. Converting precise dates from one system to the other requires the use of a formula and a series of tables. These may be found in G.S. P. Freeman-Grenville, The Muslim and Christian Calendars (London, 1963).

The Muslim lunar months are as follows:

Muharram

Safar

Rabi' al-awwal (Rabi' I)

Rabi' al-thani (Rabi' II)

Jumada I-ula (Jumada I)

Jumada 1-akhira (Jumada II)
Rajab

Sha'ban

Ramadan

Shawwal

Dhu I-Qa'da

Dhu l-Hijja 